\title{
Hidrostratigrafi Akuifer dan Estimasi Potensi Airtanah Bebas Guna Mendukung Kebutuhan Air Domestik Desa Sembungan
}

\author{
Anindya Arma Risanti, Kurniawan Andre Cahyono, Latifah, Melati Ayuning Putri, Novita Rahmawati, \\ Roesdi Fitra Ariefin,Safira Prameswari, Wisnu Agung Waskito, Tjahyo Nugroho Adji, dan Ahmad Cahyadi
}

Fakultas Geografi, Universitas Gadjah Mada, Yogyakarta, Indonesia

Email Koresponden:Anindya.arma.r@mail.ugm.ac.id

Diterima: Januari 2018 /Disetujui: Februari 2018 / Publikasi online: Maret 2018

(c) 2018 Fakultas Geografi UGM dan Ikatan Geograf Indonesia (IGI)

\begin{abstract}
Abstrak Desa Sembungan termasuk desa yang berbasis pada sektor pertanian dan pariwisata. Seiring berkembangnya sektor tersebut, perlu adanya kajian airtanah khususnya untuk kebutuhan domestik. Kuantitas airtanah pada suatu daerah sangat berkaitan dengan sistem dan karakteristik akuifer batuan penyusunnya. Tujuan dari penelitian adalah (1) menganalisis struktur hidrostratigrafi akuifer di Desa Sembungan dan (2) mengetahui potensi airtanah bebas untuk kebutuhan air domestik di Desa Sembungan. Penelitian ini menggunakan metode geolistrik tahanan jenis konfigurasi Schlumberger dalam investigasi keberadaan airtanah untuk mencapai tujuan pertama dan wawancara jenuh terkait penggunaan kebutuhan air domestik untuk mencapai tujuan kedua. Hasil penelitian menunjukkan bahwa akuifer Desa Sembungan merupakan akuifer bebas dengan lapisan akuifer terdiri dari lapisan lempung, airtanah, andesit basaltic dan endapan tuffan alterasi. Ketebalan akuifer berkisar 3 hingga 7,8 meter. Desa Sembungan memiliki potensi airtanah bebas sebesar 5,47 milyar liter untuk kebutuhan air domestik dalam satu tahun sebesar 87.994.985,3 liter/tahun sehingga Desa Sembungan memiliki potensi airtanah dengan kuantitas yang besar dan mencukupi kebutuhan masyarakat.
\end{abstract}

Kata kunci: struktur hidrostratigrafi, potensi airtanah bebas, kebutuhan domestik

\begin{abstract}
Sembungan Village based on the agricultural sector and tourism. As the sector develops, study of groundwater related to the domestic sector. Groundwater quantity mostly related to the system and the characteristics layer of material aquifer. The purpose of the research are (1) to analyze the hydrostratigraphic structure in Sembungan Village and (2) to know the groundwater potential for domestic water needs in Sembungan Village. This research used the resistivity geoelectric method i.e the Schlumberger configuration to get the first goaland conducted saturated interviews related to the use of domestic water needs to get the second goal. The result showed that the Sembungan Village aquifer is unconfined aquiferwithaquifer consist of clay, groundwater, andesite basaltic and sediment tuffan alteration. The aquifer thickness was ranging 3-7,8 $\mathrm{m}$. Sembungan Village has 5.47 billion liters of groundwater and domestic water needs in one year has reached to 87.994.985,3 liter / year so Sembungan Village has the groundwater potential with a large quantity and sufficient community needs.
\end{abstract}

Key words: hydrostratigraphic structure, groundwater potential, domestic water needs

\section{PENDAHULUAN}

Desa Sembungan merupakan salah satu desa yang terletak di kompleks Gunungapi Dieng bagian timur dengan luas 291.730 hektar. Desa Sembungan termasuk desa yang berbasis pada sektor pertanian dan pariwisata. Sektor pariwisata sangat berkembang pesat, sehingga banyak permukiman yang dijadikan penginapan (homestay). Hal ini untuk meningkatkan perekonomian warga sekitar. Selain itu, sektor pertanian yang berkembang secara intensif adalah pertanian kentang yang cenderung tidak mampu dalam menahan air. Oleh sebab itu, jumlah airtanah diperkirakan semakin berkurang.

Seiring dengan berkembangnya sektor pariwisata dan pertanian, perlu adanya kajian mengenai airtanah yang terkait dengan sektor domestik di Desa Sembungan. Setiap penduduk memerlukan airtanah untuk mendukung pemenuhan kebutuhan sehari-hari, sehingga sektor domestik merupakan salah satu sektor yang paling penting terkait dengan keberadaan airtanah. Terlebih jumlah penduduk Desa Sembungan semakin meningkat setiap tahunnya. Apabila kuantitas airtanah tidak dapat mendukung kebutuhan air domestik, maka kebutuhan airtanah pada sektor lain tidak akan dapat terpenuhi.

Kuantitas airtanah pada suatu daerah sangat berkaitan dengan sistem dan karakteristikakuifer batuan penyusunnya. Menurut Fetter (1988), variasi litologi penyusun dan struktur geologi akan berpengaruh terhadap karakteristik akuifer, potensi, dan dinamika airtanah di dalamnya. Variasi litologi penyusun pada suatu daerah dapat diketahui dari suatu identifikasi dan analisis hidrostratigrafi. Hasil dari identifikasi dan analisis hidrostratigrafi akan didapatkan ketebalan akuifer, sehingga dapat dihitung volume airtanah yang dapat tertampung pada daerah tersebut. 
Identifikasi hidrostratigrafi dapat dilakukan dengan pendugaan geolistrik. Metode geolistrik merupakan salah satu metode geofisika yang digunakan untuk melakukan pendugaan bawah permukaan sebagai objek utamanya (Raghunath, 1987). Penggunaan metode geolistrik bertujuan untuk mengetahui lapisan bawah permukaan bumi, sehingga diketahui kemungkinan keterdapatan airtanah dan mineral pada kedalaman tertentu (Halik dan Soetjipto, 2008). Material-material bawah permukaan Bumi apabila dialiri arus listrik akan mempunyai perbedaan tahanan jenis yang khas. Oleh karena itu, geolistrik menggunakan prinsip perbedaan nilai tahanan jenis tiap jenis batuan dalam penentuan keterdapatan airtanah (Lowrie, 2007). Penelitian ini memiliki tujuan sebagai berikut (1) menganalisis struktur hidrostratigrafi wilayah kajian untuk identifikasi karakteristik akuifer dan (2) mengetahui volume airtanah bebas dan kebutuhan air domestik di Desa Sembungan guna mengetahui potensi airtanah untuk mendukung kebutuhan air domestik.

\section{METODE PENELITIAN}

Penelitian ini merupakan penelitian deskriptif kuantitatif, yaitu bertujuan untuk mendiskripsikan hidrostratigrafi akuifer bebas di sebagian Desa Sembungan serta mengetahui potensi volume statis airtanah guna mendukung kebutuhan air domestik di Desa Sembungan. Metode yang digunakan dalam penelitian ini terdiri atas 3 tahap. Tahap persiapan terdiri atas pengumpulan data sekunder yang akan digunakan terkait dengan penelitian (peta geomorfologi, nilai specific yield dan monografi desa), orientasi lapangan untuk mengetahui kondisi daerah penelitian dan mempersiapkan peralatan lapangan, serta penentuan titik lapangan untuk melakukan uji geolistrik. Tahap pengumpulan data lapangan terdiri atas uji geolistrik di beberapa titik di Desa Sembungan, perhitungan volume statis dan wawancara terkait kebutuhan air domestik. Tahap analisis dan perumusan hasil terdiri atas analisis hasil uji geolistrik, hasil perhitungan volume statis dan hasil wawancara kebutuhan air domestik.

Data yang digunakan dalam penelitian ini terdiri atas data primer dan data sekunder. Data primer antara lain berupa data material bawah permukaan hasil dari pendugaan geolistrik yang dikorelasikan dengan nilai permeabilitas (Tabel 1) sebagai perhitungan potensi airtanah statis, perlapisan akuifer, tebal akuifer, dan volume tampungan air di rumah-rumah penduduk. Data sekunder meliputi nilai specific yield (Tabel 2); Peta Geomorfologi DAS Lempong, Sembungan, Kejajar, Wonosobo skala 1:10.000; dan Peta Geologi Lembar Banjarnegara dan Pekalongan skala 1:100.000. Sampling dari penelitian ini terdiri dari 2 teknik, pertama untuk pendugaan geolistrik dilakukan purposive sampling dalam menentukan titik yang merepresentasikan material akuifer bebas Desa Sembungan. Titik pengukuran geolistrik ditentukan berdasarkan beberapa kriteria, diantaranya: 1) permukaan tanah tempat pengukuran geolistrik sebaiknya dipilih permukaan yang datar dan terbuka yang memungkinkan untuk bentangan kabel-kabel elektroda, 2) rentangan kabel elektroda harus tegak lurus dengan arah aliran airtanah, atau sejajar dengan kontur, 3) tidak dianjurkan untuk merentangkan kabel diatas lahan yang basah atau tergenang air, 4) sangat tidak disarankan merentangkan kabel dibawah arus tegangan listrik, 5) lokasi pengukuran sebaiknya tidak terpengaruh oleh medan listrik atau medan magnet yang berasal dari sumber terdekat apapun, dan 6) sebaiknya lokasi pengukuran geolistrik bukan merupakan bekas penimbunan bahanbahan bangunan, sampah, dan lain sebagainya (Santosa dan Adji, 2006). Teknik kedua dilakukan wawancara jenuh terkait penggunaan kebutuhan air domestik, sehingga diperoleh data kebutuhan air orang per hari/ liter.

Pengukuran geolistrik dilakukan di tiga titik dengan menggunakan metode Vertical Electrical Sounding (VES) dan konfigurasi Schlumberger. Konfigurasi Schlumberger dipilih karena konfigurasi ini baik digunakan untuk mengetahui lapisan-lapisan batuan ke arah dalam secara vertikal (Santosa, 2001). Hasil dari geolistrik adalah nilai resistivitas material (nilai tahanan jenis) melalui pengukuran kuat arus, jarak antar elektrode dan beda potensial. Data pengukuran Geolistrik dimasukkan dalam software IP2Win, kemudian hasil analisis menggunakan interpretasi material atau batuan pada wilayah kajian didasarkan pada tabel resistivitas material yang dikemukakan oleh Telford (1990) tertera pada Tabel 3.

Perhitungan kuantitas airtanah metode statis menganggap bahwa akuifer dianggap sebagai suatu wadah yang menampung sejumlah airtanah dengan-

Tabel 1. Nilai permeabilitas dari berbagai jenis material batuan

\begin{tabular}{lc}
\hline \multicolumn{1}{c}{ Material } & Permeabilitas (m/hari) \\
\hline Kerikil kasar & 150 \\
Kerikil sedang & 270 \\
Kerikil halus & 450 \\
Pasir kasar & 45 \\
Pasir sedang & 12 \\
Pasir halus & 2,5 \\
Lanau & 0,08 \\
Lempung & 0,0002 \\
Batu pasir halus & 0,2 \\
Batu pasir sedang & 3,1 \\
Batu gamping & 0,94 \\
Pasir gumuk & 20 \\
Gambut & 5,7 \\
Sekis & 0,2 \\
Batusabak & 0,00008 \\
Tuf & 0,2 \\
Basal & 0,01 \\
Gabro lapuk & 0,2 \\
Granit lapuk & 1,4 \\
\hline Sumber: Morris dan Johnson dalam Purnama, 2010.
\end{tabular}

Sumber: Morris dan Johnson dalam Purnama, 2010. 
Tabel 2. Specific yield dari berbagai batuan

\begin{tabular}{ccc}
\hline Material & Porositas & $\begin{array}{c}\text { Specific } \\
\text { yield }\end{array}$ \\
\hline Soil & 55 & 40 \\
Clay & 50 & 2 \\
Sand & 25 & 22 \\
Gravel & 20 & 19 \\
Limestone & 20 & 18 \\
Sandstone & 11 & 6 \\
Granite & 0.1 & 0.09 \\
Basalt (young) & 11 & 8 \\
\hline
\end{tabular}

Sumber: Heath, 1983.

kemampuan atau volume tertentu. Pendekatan statis menggunakan parameter luasan area, tebal akuifer dan hasil jenis (specific yield). Perhitungan volume airtanah metode statis menggunakan rumus (Purnama, 2010):

Vat $=$ Sy $x$ Vak

\section{Keterangan:}

Vat = Volume airtanah yang dapat lepas dari akuifer

Sy = Specific Yield atau persentase air yang dapat lepas dari akuifer

Vak = Volume akuifer (luas penampang akuifer dikalikan dengan tebal akuifer).

Tabel 3. Hubungan tahanan jenis dengan batuan

\begin{tabular}{lc}
\hline \multicolumn{1}{c}{ Material } & $\begin{array}{c}\text { Resistivitas } \\
(\text { Ohm-meter })\end{array}$ \\
\hline Air (Udara) & 0 \\
Sandstones (Batu & $200-8.000$ \\
Pasir) & \\
Sand (Pasir) & $1-1.000$ \\
Clay (Lempung) & $1-100$ \\
Andesite (Andesit) & $1.7 \times 10^{2}-45 \times 10^{4}$ \\
Groundwater & $0.5-300$ \\
(Airtanah) & 0.2 \\
Sea Water (Air Asin) & $600-10.000$ \\
Dry Gravel (Kerikil & $10-800$ \\
Kering) & $100-600$ \\
Alluvium (Aluvium) & \\
Gravel (Kerikil) &
\end{tabular}

Sumber: Telford, 1990

Kebutuhan air domestik dihitung menggunakan data jumlah penduduk dan volume tampungan air yang digunakan, selanjutnya kebutuhan air domestik per rumah tangga diubah menjadi data kebutuhan air per orang per hari. Data kebutuhan air per orang/liter yang digunakan oleh masyarakat untuk kebutuhan air domestik diperoleh dari hasil wawancara jenuh hingga memperoleh jawaban yang sama dari sampel yang akan digunakan. Data kebutuhan air domestik dihitung dalam penggunaan satu tahun, kemudian dibandingkan dengan volume airtanah sebagian.

\section{HASIL DAN PEMBAHASAN}

Analisis struktur hidrostratigrafi wilayah kajian untuk identifikasi karakteristik akuifer dilakukan dengan pengukuran dan interpretasi data geolistrik. Pengukuran geolistrik dilakukan pada tiga titik pengukuran (Gambar 1). Titik pengukuran pertama dilakukan di lapangan parkir sebelah utara Telaga Cebong. Titik pengukuran kedua dilakukan di wilayah perkemahan Telaga Cebong yang berada di sisi timur telaga. Titik pengukuran ketiga dilakukan di tepi pintu masuk Desa Sembungan. Titik pengukuran dipilih dengan purposive sampling yaitu pada kondisi tanah yang relatif datar dan terbuka, tidak ada genangan atau jauh dari perairan, bukan merupakan tanah urukan dengan sedikit penghalang atau diusahakan bukan tempat aktivitas warga yang intensif.

Interpretasi data geolistrik dilakukan setelah pengolahan data dengan software IP2Win. Interpretasi material atau batuan pada wilayah kajian didasarkan pada tabel resistivitas material yang dikemukakan oleh Telford (1990) dan dihubungkan dengan peta geologi dan survei lapangan sebagai validasi hasil interpretasi material dari pendugaan geolistrik.

Berdasarkan survei lapangan, didapatkan batuan basalt, diorit, dan endapan tuffan alterasi. Batuan basalt dan diorit dijumpai pada kedalaman lebih dari 10 meter dari permukaan tanah dan didapatkan dari penduduk yang sedang membuat sumur bor. Lapisan endapan tuffan alterasi dijumpai pada singkapan batuan yang berada sekitar 15 meter di bawah titik uji geolistrik ketiga (G3). Berdasarkan survei tingi muka airtanah (TMA), lapisan akuifer atau airtanah pada wilayah permukiman yang berada di bawah titik uji geolistik ketiga (G3) didapatkan pada kedalaman sekitar 9,42 hingga 12,6 meter dari permukaan tanah.

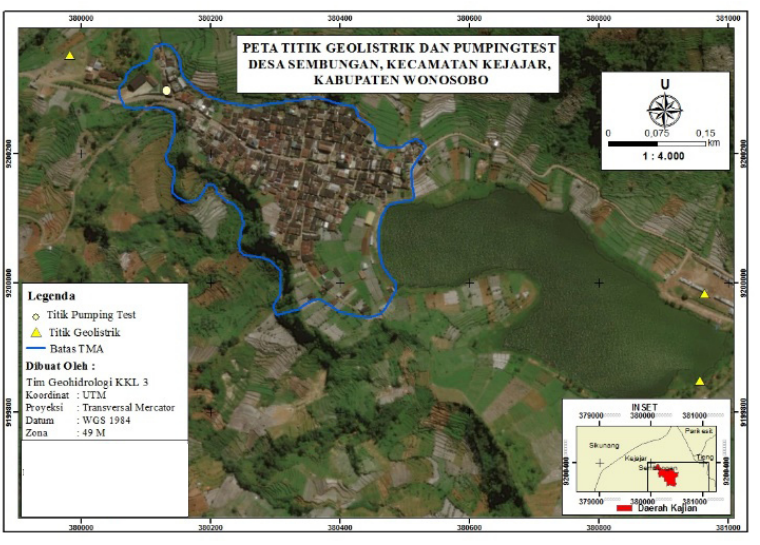

Gambar 1. Peta lokasi pengukuran geolistrik Sumber: Waskito, 2017 


\section{Titik Uji Geolistrik Pertama (G1)}

Titik pengukuran geolistrik pertama berada di sisi utara Telaga Cebong memiliki 5 perlapisan. Lapisan atas pada titik tersebut adalah tanah urukan setebal 3,14 meter dari permukaan tanah. Tanah urukan teridentifikasi dari nilai resistivitas material yang teridentifikasi sebesar 19,1 $\Omega$ m. Kekurangan pengukuran geolistrik pada titik pengukuran pertama adalah pengukuran geolistrik dilakukan diatas tanah urukan yang cukup tebal, sehingga kemungkinan kesalahan interpretasi material apabila material yang digunakan sebagai bahan urukan bukan terbentuk ataupun terendapkan secara alami pada daerah tersebut.

Lapisan endapan danau jenuh airtanah teridentifikasi dibawah lapisan tanah urukan. Lapisan endapan danau jenuh air teridentifikasi hingga kedalaman 5,84 meter dari permukaan tanah. Lapisan tersebut diidentifikasi sebagai endapan danau karena memiliki resistivitas yang rendah, yaitu sekitar 1,12 hingga $8,07 \Omega \mathrm{m}$.

Lapisan koluvial ditemukan di bawah lapisan endapan danau jenuh air hingga kedalaman 7,14 meter. Lapisan koluvial tersebut memiliki nilai resistivitas $405 \Omega \mathrm{m}$. Lapisan koluvial tersebut terbentuk dari sedimentasi material hasil erosi yang berasal dari Bukit Sikunir yang terbawa oleh pengaruh gaya gravitasi. Lapisan akuifer teridentifikasi pada kedalaman 7,14 hingga 14,9 meter dari permukaan tanah. Lapisan tersebut memiliki nilai resistivitas sebesar $10,1 \Omega \mathrm{m}$ sehingga teridentifikasi sebagai lapisan pasir jenuh air (akuifer). Lapisan lempung ditemukan juga pada kedalaman 14,9 hingga 21,7 meter. Keterdapatan lapisan lempung dicirikan dengan nilai resistivitas material yang tinggi. Resistivitas material yang tinggi sebesar $5.452 \Omega$ m menandakan bahwa material susah untuk menghantarkan listrik dengan baik. Oleh karena itu, material lempung juga akan susah untuk meloloskan air.

\section{Titik Uji Geolistrik Kedua (G2)}

Titik pengukuran geolistrik kedua (G2) yang berada di sisi timur Telaga Cebong memiliki lima perlapisan. Lapisan atas pada titik tersebut adalah endapan BukitSikunir setebal2,79meter daripermukaan tanah. Endapan Bukit Sikunir teridentifikasi dari nilai resistivitas material sebesar 1,41 $\Omega \mathrm{m}$. Lapisan ini dapat juga diidentifikasi sebagai endapan danau jenuh air karena memiliki resistivitas yang rendah. Rendahnya resistivitas yang dimiliki oleh material pada lapisan ini disebabkan karena adanya air yang memenuhi zona aerasi akibat dari hujan yang terjadi pada malam hari sebelum pengukuran geolistrik pada titik ini.

Lapisan akuifer teridentifikasi dibawah lapisan tanah urukan. Lapisan akuifer teridentifikasi hingga kedalaman 5,02 meter dari permukaan tanah. Lapisan tersebut memiliki nilai resistivitas sebesar 10,4 $\Omega \mathrm{m}$, sehingga teridentifikasi sebagai lapisan pasir jenuh air (akuifer). Lapisan ketiga pada titik G2 adalah endapan danau jenuh air yang berada pada kedalaman 5,02 hingga 10,5 meter dari permukaan tanah. Lapisan endapan danau jenuh air ini memiliki resistivitas sebesar 1,51 $\Omega \mathrm{m}$. Lapisan yang berada di bawahnya merupakan lapisan endapan danau kering yang berada pada kedalaman 10,5 hingga 21,9 meter. Lapisan endapan danau kering teridentifikasi karena memiliki nilai resistivitas yang tinggi yaitu sebesar $616 \Omega \mathrm{m}$.

Lapisanterakhiryangberadapadatitikpengukuran geolistrik kedua (G2) adalah lapisan Andesit Basaltik. Lapisan Andesit Basaltik ditemukan pada kedalaman 21,9 hingga 54,8 meter. Lapisan ini memiliki nilai resistivitas sebesar $2.295 \Omega \mathrm{m}$. Nilai resitivitas yang sangat besar pada lapisan ini disebabkan karena material andesit basaltik bersifat impermeable sehingga kedap air dan sulit menghantarkan listrik. Lapisan Andesit Basaltik dapat dibuktikan keberadaannya pada Peta Geologi Lembar Banjarnegara dan Pekalongan skala 1:100.000 yang dibuat oleh Pusat Penelitian dan Pengembangan Geologi, Dinas ESDM.

Berdasarkan Peta Geologi Lembar Banjarnegara dan Pekalongan skala 1:100.000 disebutkan bahwa Desa Sembungan secara umum tersusun atas formasi Batuan Gunungapi Dieng muda (Qdy). Formasi Batuan Gunungapi Dieng muda terdiri atas lava andesit dan andesit-kuarsa, serta batuan klastika gunungapi. Namun, jenis batuan yang ditemukan di lapangan adalah basalt karena sifat letusan dari Gunungapi Dieng bersifat basa, sehingga lapisan impermeable yang teridentifikasi adalah andesit basaltik. Identifikasi tersebut diperkuat dengan temuan batuan hasil dari galian sumur berupa basalt (beku ekstrusif) serta diorit (beku instrusif) (Gambar 2). Hal tersebut memperkuat bahwa Desa Sembungan berasosiasi terhadap proses geomorfik vulkanik.

\section{Titik Uji Geolistrik Ketiga (G3)}

Pengukuran geolistrik pada titik ini dilakukan ketika hujan. Kesalahan interpretasi material pada titik ini sangat mungkin terjadi karena pada zona aerasi dipenuhi oleh air hujan. Titik pengukuran geolistrik ketiga (G3) yang berada di tepi pintu masuk Desa Sembungan memiliki lima perlapisan. Lapisan atas pada titik tersebut adalah tanah urukan setebal 6,08 meter dari permukaan tanah. Lapisan tanah urukan teridentifikasi dari nilai resistivitas material yang teridentifikasi sebesar 27 hingga $39.257 \Omega \mathrm{m}$. 


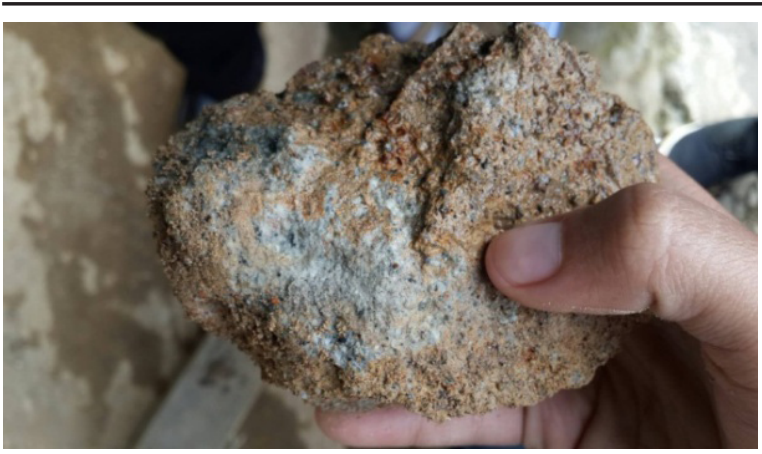

Gambar 2. Batu diorit, hasil dari galian sumur warga (Foto oleh Putri, 2017)

Lapisan akuifer kedua dan ketiga yang teridentifikasi adalah lapisan kerikil dan pasir kering. Kedua lapisan ini memiliki resistivitas yang cukup tinggi yaitu sekitar 117 hingga $634 \Omega \mathrm{m}$. Lapisan kerikil dan pasir kering ditemukan pada kedalaman 6,08 hingga 6,65 meter dari permukaan tanah. Dimungkinkan kedua lapisan ini merupakan lapisan dasar dari tanah urukan untuk menguatkan urukan karena titik pengukuran berada pada jalan yang sering dilalui oleh kendaraan berat.

Lapisan keempat yang teridentifikasi adalah lapisan airtanah (akuifer). Lapisan akuifer ditemukan pada kedalaman 6,65 hingga 14 meter dari permukaan tanah. Lapisan ini memiliki nilai resistivitas sebesar 20 $\Omega \mathrm{m}$. Lapisan terakhir yang berada pada titik pengukuran geolistrik ketiga (G3) adalah Lapisan Endapan Tufan Alterasi. Lapisan Endapan Tuffan Alterasi ditemukan pada kedalaman 14 hingga 35,9 meter. Lapisan ini memiliki nilai resistivitas sebesar $0,169 \Omega \mathrm{m}$. Nilai resitivitas yang sangat rendah pada lapisan ini dapat teridentifikasi sebagai lapisan impermeable yang mudah menghantarkan listrik. Lapisan Endapan Tufan Alterasi dapat dibuktikan keberadaannya karena pada singkapan batuan yang ditemukan sekitar 30 meter dari titik G3 merupakan perlapisan endapan tufan alterasi yang berupa batuan berwarna putih kemerahan.

Batuan alterasi ditemukan didaerah kajian diestimasikan hasil dari alterasi hidrotermal (Gambar 3).

Gambar 3. Kenampakan batuan alterasi hidrotermal



(Foto oleh Cahyono, 2017)
Kehadiran sistem hidrotermal di permukaan merupakan implikasi adanya sistem hidrotermal lainnya yang kemungkinan tertutup oleh endapan kuarter yang cukup tebal atau berada dibawah permukaan.

Berdasarkan data geolistrik pada tiga titik pengukuran dapat diketahui bahwa akuifer Desa Sembungan merupakan akuifer bebas.Hal tersebut disebabkan tidak ditemukannya lapisan impermeable di atas lapisan akuifer. Airtanah pada akuifer Desa Sembungan memiliki input dari air hujan dan dapat dimanfaatkan dengan mudah. Akuifer bebas di Desa Sembungan rentan tercemar karena sumber pencemar dapat dengan mudah teralirkan hingga lapisan akuifer.

Berdasarkan data geolistrik, maka dapat dilakukan perhitungan potensi airtanah statis atau volume airtanah bebas. Estimasi perhitungan potensi airtanah statis jika airtanah dianggap diam. Perhitungan kuantitas airtanah metode statis menganggap bahwa akuifer dianggap sebagai suatu wadah yang menampung sejumlah airtanah dengan kemampuan atau volume tertentu. Pendekatan statis menggunakan parameter luasan area, tebal akuifer dan hasil jenis (specific yield).Tebal akuifer dan hasil jenis dapat diketahui melalui korelasi data geolistrik yang dilakukan di lapangan (Gambar 4).

Identifikasi ketebalan akuifer Desa Sembungan sebesar $14 \mathrm{~m}$. Namun, tebal akuifer yang digunakan dalam perhitungan airtanah statis merupakan tebal akuifer jenuh.Penggunaan tebal akufer jenuh untuk menggambarkan reservoir airtanah Desa Sembungan, sehingga mampu menggambarkan volume airtanah disebuah sistem airtanah.Tebal akuifer jenuh yang dimaksud adalah lapisan yang diestimasikan terdapat airtanah atau zona dimana batuan jenuh dengan air. Hasil dari pendugaan geolistrik akuifer jenuh memiliki ketebalan 7,35 m.

Hasil jenis (specific yield) diperoleh berdasarkan data pumping test di Desa-

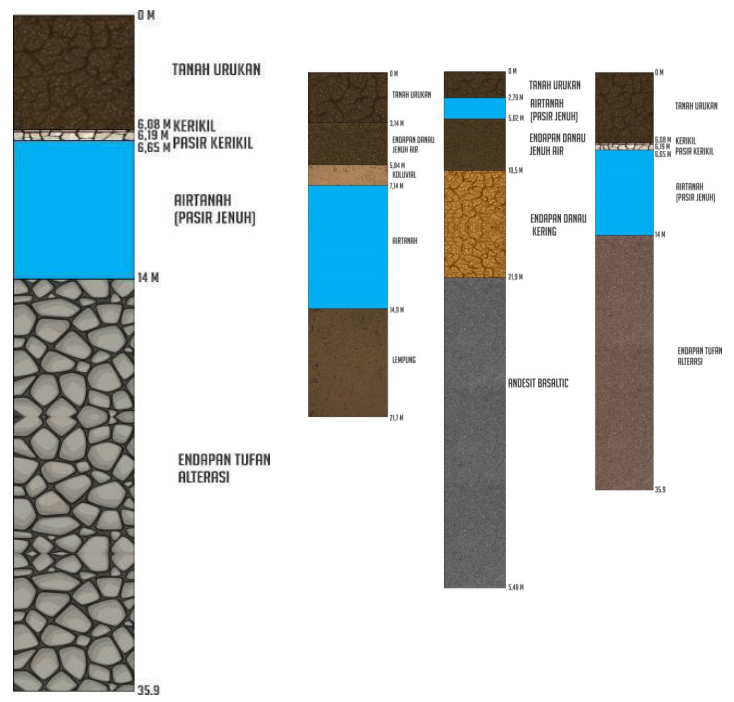

Gambar 4. Hasil interpretasi pendugaan geolistrik pada titik ketiga 
Sembungan didapatkan nilai permeabilitas sebesar $0,0196 \mathrm{~m} /$ hari.

Perhitungan metode statis di butuhkan nilai permeabilitas untuk mengkorelasikan hasil dari pendugaan material dari geolistrik dengan kemampuan batuan atau material untuk meloloskan air. Menurut Purnama (2010) (Tabel 1) litologi dengan nilai tersebut merupakan jenis material batuan basal.

Material berkaitan dengan nilai specific yield. Menurut Heath (1983), material basal memiliki nilai specific yield sebesar 8\% (Tabel 2). Sehingga volume cadangan statis airtanah diketahui dengan mengalikan ketebalan akuifer dengan luas daerah sistem airtanah Desa Sembungan sebesar 92027,87 m² dan hasil jenis (specific yield), maka didapatkan hasil sebesar 5.470.038,72 $\mathrm{m}^{3}$. Apabila dikonversi menjadi liter diperoleh hasil 5,47 milyar liter airtanah yang tertampung di sistem airtanah Desa Sembungan.

Berdasarkan hasil perhitungan tersebut dengan suplai 5,47 milyar liter air dari sistem airtanah sembungan, daerah tersebut memiliki potensi airtanah yang besar sebagai fungsi recharge area. Hal tersebut dapat dimanfaatkan untuk kebutuhan domestik dan pariwisata. Kebutuhan air domestik merupakan kebutuhan sehari-hari yang digunakan pada tempat hunian pribadi untuk memenuhi kebutuhan hidup seperti mandi, mencuci, memasak, serta keperluan rumah tangga lainnya.

Berdasarkan hasil wawancara dengan $24 \mathrm{KK}$, maka diperoleh jumlah penggunaan air/orang/liter/ hari adalah 167,77 liter/orang/hari. Oleh sebab itu, kebutuhan air dalam 1 tahun dapat diperoleh dengan mengalikan volume kebutuhan air/orang/hari dengan jumlah penduduk Desa Sembungan dikalikan dalam satu tahun, didapatkan nilai 87.994.985,3 liter/tahun.

- Penggunaan air tersebut termasuk dalam kategori tinggi untuk sebuah desa, hal tersebut dikarenakan standar kebutuhan air tiap orang per hari untuk penduduk pedesaan menurut Direktoral Jenderal Cipta Karya adalah sebesar 60 liter/kapita/hari, sehingga kebutuhan airtanah Desa Sembungan melampaui batas normal kebutuhan air domestik suatu desa. Diindikasikan kebutuhan air domestik per orang/hari melampaui batas kebutuhan air domestik desa karena untuk kepentingan mencuci pakaian dari ladang yang membutuhkan air yang terbilang lebih banyak.

\section{KESIMPULAN}

Hidrostratigrafi wilayah kajian untuk karakteristik akuifer berdasarkan material dan perlapisan menurut tabel resistivitas material yang dikemukakan oleh Telford (1990). Hasil pengukuran geolistrik menunjukkan bahwa akuifer pada Desa Sembungan merupakan akuifer bebas, dengan ketebalan akuifer jenuh berkisar
3 - 7,8 meter. Akuifer yang mendominasi terdiri atas lapisan lempung, airtanah, andesit basaltik dan endapan tuffan alterasi.

Perhitungan potensi airtanah statis atau volume airtanah bebas yaitu menunjukkan 5,47 milyar liter airtanah, serta untuk kebutuhan air domestik penududuk Desa Sembungan menunjukkan nilai jumlah penggunaan air 167,77 liter/orang/hari; dan memiliki jumlah penduduk sebanyak 1.437 jiwa, sehingga kebutuhan air domestik penduduk Desa Sembungan menunjukkan nilai 241.082,15liter/hari serta dalam satu tahun memilki kebutuhan air domestik sebesar 87.994.985,3 liter/tahun.

\section{UCAPAN TERIMAKASIH}

Penulis mengucapkan terimakasih kepada Kepala Desa Sembungan dan jajaran Pemerintah Wonosobo yang telah membantu berlangsungnya kegiatan penelitian baik secara langsung ataupun tidak langsung. Terimakasih kepada Lilik Ismangil sebagai tim teknisi dari Laboratorium Hidrologi dan Klimatologi Lingkungan Fakultas Geografi UGM yang telah memberikan kontribusinya dalam kegiatan pengambilan data geolistrik di lapangan. Terimakasih juga penulis sampaikan kepada semua tim kuliah kerja lapangan (KKL) 3 serta segenap dosen pembimbing kuliah kerja lapangan (KKL) 3 Departemen Geografi Lingkungan Fakultas Geografi Tahun 2017 yang telah memberi arahan dan ijin sehingga penelitian ini dapat berlangsung.

\section{DAFTAR PUSTAKA}

Departemen PU, (1998). Petunjuk Teknis Perencanaan Rancangan Teknik Sistem Penyediaan Air Minum Perkotaan, DPU Direktorat Jenderal Cipta Karya, Jakarta.

Fetter, C. W., (1988). Applied Hydrogeology, Ohio: Merril Publishing Company.

Halik, G. dan Soetjipto, J.W., (2008). Pendugaan Potensi Air Tanah dengan Metode Geolistrik Konfigurasi Schlumberger di Kampus Tegal Boto Universitas Jember, Jurnal Media Teknik Sipil.

Heath, R. C., (1983). Basic Ground-Water Hydrology, U.S. Geological Survey Water-Supply Paper 2220.

Lowrie, W., (2007). Fundamental of Geophysics Second Edition, New York: Cambridge University Press.

Purnama, S., (2010). Hidrologi Air Tanah, Yogyakarta: Kanisius.

Raghunath, H.M., (1987). Ground Water Second Editio,New Delhi: Wiley EasternLimited.

Santosa, L.W., (2001). Hidrostratigrafi dan Hidrokimia Airtanah di Sekitar Rowo Jombor Kecamatan Bayat-Klaten, Majalah Geografi Indonesia. Vol.15, No.2, September 2001. 165-184. 
Santosa, L.W. dan Adji, T.N., (2006). Penyelidikan Potensi Airtanah Cekungan Airtanah Sleman Yogyakarta di Kabupaten Bantul. Yogyakarta: CEEC.

Telford, W. M., Grldart, L. P., \& Sheriff, R. E., (1990). Applied Geophysic, Camridge: Camridge University Press. 